\title{
Compensation Theories and Expropriation of Customary Property Rights: A Critical Review
}

\author{
Lucky Kabanga ${ }^{1}$, and Manya M. Mooya ${ }^{2}$
}

1-2 Department of Construction Economics and Management, Faculty of Engineering and Built Environment, University of Cape Town

To cite this article: Kabanga, L. \& Mooya, M.M. (2018). Compensation Theories and Expropriation of Customary Property Rights: A Critical Review. Journal of African Real Estate Research, 3(2), pp.87-106. DOI: 10.15641/jarer.v3i2.487.

\begin{abstract}
Market value is the most common compensation basis for expropriation of both private and customary property rights. Private property rights are generally exchangeable while customary property rights are conceptually not as exchangeable. It is hence critical to analyse the applicability of current compensation theories, which are founded on private property rights, to different property rights and in different social settings. By using existing literature and empirical evidence from Africa and other countries where customary property rights dominate, this paper undertakes a theoretical analysis of the applicability of existing compensation theories and the methodologies used to achieve the desired compensation goals. The analysis concludes that whilst current compensation theories are broadly applicable to customary property rights as they aim to protect property rights and prevent expropriatees from impoverishment, various ontological and methodological factors limit the realisation of these goals in settings dominated by customary properties. Such factors include ontology and dominance of customary property rights, use of market value as a compensation basis, and capacity of compensation assessors. Broadly, these factors lead to inadequate compensation and impoverishment of affected people.
\end{abstract}

Keywords: Compensation; Customary Property Rights; Expropriation; Market Value; Private Property Rights.

\section{Introduction}

Provision of various public infrastructures, services and amenities like roads, railways, electricity, petroleum and gas pipelines, housing, airports, schools, hospitals, and conservation areas (Kakulu, 2008; Du Plessis, 2009; Ambaye, 2013; Denyer-Green, 2014) requires vast pieces of land that governments might not have in required quantities, locations, or spatial configurations 
(Evans, 2004). Most frequently, the required land is expropriated from various owners, whether private or customary, in return for compensation based on market value of expropriated properties. Compensation is broadly required to restore expropriatees to their previous status, and generally lessen expropriation burdens as much as possible (Barnes, 2014). Current compensation theories consider property as a well-defined and exchangeable bundle of rights with a value (Denyer-Green, 2014). And for private property rights based on a Western concept, this is true. Contrariwise, customary property rights are less defined and mostly inalienable (conceptually) (Small \& Sheehan, 2008). This view of property prevails on the African continent (Cotula \& Chauveau, 2007, Kakulu, 2008) and other developing countries (Xanthaki, 2007). With such differing ontological perceptions of property rights between private and customary, how is compensation then assessed for customary properties guided by existing compensation theories? In addressing this question, one needs to explicitly understand two key aspects: market value as the basis for assessing compensation and private property rights as the accepted foundation for current compensation theories. These two aspects are discussed in the following sections. Thus, the paper aims to critically analyse the applicability of current compensation theories and their methodologies for assessing compensation for customary properties, which differ from private properties, and the challenges faced, by using existing literature and empirical works. Further, the study intends to deepen our understanding of the core aims of current compensation theories, their prescribed basis and assessment methods, and hence the challenges faced when applied to customary properties. Additionally, the study demonstrates that existing compensation assessment methodologies contribute to inadequate compensations and impoverishment of expropriated customary land owners. The results are expected to provide a basis for further research on compensation assessment basis and methodologies in relation to the broad compensation goals stated elsewhere.

This paper has five sections. After introduction, section two discusses the two broad compensation theories while section three looks at the nature of customary property in relation to private property, before analysing the applicability of existing compensation theories and assessment methods to customary properties and their challenges. A conclusion closes the analysis.

\section{Compensation Theories}

This section discusses the main classes of compensation theories, compensation aims, basis and methods for assessing compensation for loss of property during expropriation, with a focus on customary property rights.

\subsection{Compensation Theories and Compensation Scope}

Indemnity and taker's gain are the two main groups of compensation theories, founded on compensation scopes covered to meet different compensation goals. The indemnity theory desires compensation that considers the whole range of losses to put expropriatees on a similar status as before the expropriation, but not worse-off (Denyer-Green, 2014). Characteristically, this requires compensation covering market value of property taken, plus additional compensation for severance and injurious affection, expropriatory 
disturbances, consolatory payments (solatium) and/or special values. Under this principle, compensation is measured by considering an expropriatee's losses, and not purchaser's benefits (Barnes, 2014). Various compensation concepts including adequate compensation, appropriate compensation, commensurate compensation, fair compensation, full compensation, equivalent compensation, and full indemnification, among others, subscribe to the indemnity philosophy.

Market value of acquired property is generally the principal item for compensation. Likewise, severance and injurious affection are based on market or rental values (Baum et al., 2008). Severance is loss in value of any remaining property where only a fraction of the property is expropriated, while injurious affection is depreciation in value of any remaining property caused by proposed uses on acquired land or the actual works (Barnes, 2014). Generally, depreciation in market value of remaining land is the compensation amount for severance and injurious affection.

Disturbance compensation is based on financial calculations and includes profit/income and business losses; costs for relocation and transport, legal and valuation services, among many others (Baum et al., 2008). Solatium, as a consolation payment for expropriation, is given as a lump sum or as a proportion of the agreed compensation sum (Baum et al., 2008) and varies in different jurisdictions. Special value depends on sentimental attachments between owners and the expropriated properties and benefits emanating from the property to owners besides market value (Keon-Cohen, 2002). Special value is based on a percentage of the compensation sum, or it is agreed upon by the parties (Fortes, 2005). Thus, the indemnity theory desires compensation that consists of market value of property taken, severance and injurious affection, disturbance, solatium and/or special value to restore expropriatees.

Alternatively, taker's gain theory focuses on the expropriated property. It argues that compensating the other additional items covered under the indemnity theory like disturbance, drains public resources (Kratovil \& Harrison, 1954), while enriching affected people. Since it is property that is taken, then government should compensate for that at its market value and nothing more or less. Taker's gain compensation is measured by the gains of the acquisition to the taker, and not expropriatee's losses (Kratovil \& Harrison, 1954). As such, compensation under taker's gain usually consists of market value of acquired property, which also measures adequacy of compensation required to restore affected people. Thus, all compensation principles focusing only on expropriated property belong to takers' gain theory.

\subsection{Compensation Aims}

Compensation serves several purposes and the following sections discuss some of the major ones. In the first place, many societies require compensation to defend their property rights from idiosyncratic decisions and actions of government (Nosal, 2001). Further, property is believed to be strongly attached to its owners and gives them identity and contextuality, while connecting intricately with individuals, families and communities 
(Radin, 1982). As such, many national constitutions knowingly contain compensation principles aimed to protect property from predatory authorities (Food and Agricultural Organisation, 2012) and people. It is thus presumed that expropriation without compensation would not be permissible (DenyerGreen, 2014). Consequently, the sheer need for acquiring authorities to pay compensation provides, and increases, protection for property rights.

Second, where private property rights are allowed and government wants to expropriate such property, then it must pay prevailing prices to prevent arbitrary deprivation and gains (Du Plessis, 2009). Blackstone (1872) contended that in such a setting government is treated as any other private individual dealing with another private individual in a private exchange and at a reasonable price. Principally, government can expropriate any private property, but in exchange for an equivalent price as in an open and objective exchange, and not otherwise (Barnes, 2014). Consequently, ruling prices are believed to dissuade government from getting property by using its advantageous position and essentially deterring arbitrary purchases and gains.

Seemingly, expropriatees replace lost properties from the market by using the compensation money received. Then theoretically, compensation that satisfies and guarantees an anxious and unwilling person of a replacement property compels that individual to surrender his/her property keenly (Denyer-Green, 2014). Thus, according to Denyer-Green (2014), the owner's monetary loss must be ascertained by determining the true pecuniary value of the property taken, and not below market prices, and the affected person must be fully compensated based on that value. However, claims of insufficient government resources, saving agendas or not wanting to appear as paying too much compensation, and property grabbing (Cotula et al., 2009, Chinsinga \& Wren-Lewis, 2013), undermine acceptable restoration and impoverish affected persons (Kaufman, 2010). Walker (2008) also blames opportunistic conducts through corruption by officials involved in expropriation, restitution and restoration to contribute to impoverishing affected people and missing intended goals, as evidenced in Limpopo and Mpumalanga in South Africa. This has also been observed in Tanzania (Kombe, 2010), Ethiopia (Alemu, 2013), Nigeria (Famuyiwa, 2011), Ghana (Larbi et al., 2004), and other African countries (Cotula et al., 2009). Beyond Africa, corruption and other opportunistic tendencies also surface in India (Asian Development Bank, 2007), China (Alias et al., 2006), and many other countries (Deininger, 2003). These compensation goals are discussed further in section four in relation to customary property rights. However, to better appreciate compensation aims, we need to first understand the assessment basis and methods for compensation, as discussed below.

\subsection{Compensation Assessment Basis and Methods}

Market value is the general basis for assessing compensation. According to the International Valuation Standards Council (2017), market value is the estimated amount for which an asset or liability should exchange on the valuation date between a willing buyer and a willing seller in an arm's length transaction after proper marketing and where the parties had each acted knowledgeably, prudently and without compulsion. 
Market value is believed to clearly describe property value and the valuation process, and is thus considered as the best basis for valuation for various purposes (Baum et al., 2008). It is presumably assessed objectively and authenticated externally through market evidence. It is argued that market value achieves fair and efficient expropriation as expropriatees get compensation that enables them to replace lost properties from the market (Denyer-Green, 2014). Additionally, the market is considered as a neutral measure for property values due to objective interaction of demand and supply. Ironically, Kelly (2006) argues that it is difficult to fix the value that owners attach to their properties using market value as it ignores some real aspects of the property, such as sentimental attachment, (Kaufman, 2010, Mitchell et al., 2015), long occupation, and personal adaptations (DenyerGreen, 2014). Consequently, market value does not always equal owner's real loss and so, insufficiently indemnifies loss of private property.

Practically, market value assessment uses comparison, income and cost approaches that are market-reliant. Comparison methods compare subject properties with similar properties traded recently in the market to estimate value, and the use of direct comparable transactions is trusted to reduce uncertainties, unlike in other methods (Blackledge, 2009), such as income and cost approaches. Income approaches capitalise income into value. Capitalisation translates income into a present amount by using a suitable discount rate (Scarrett, 2008). In principle, value is found through dividing the property's net income by a discount rate. Alternatively, for cost techniques property value is the sum of land value and the depreciated current cost of reproducing or replacing the improvement (Blackledge, 2009). Cost methods are used when the other approaches cannot be reliably applied, or to supplement them. Now, in order to comprehend the relationship of compensation assessment basis and methods with property rights, there is a need to understand the nature of customary and private property rights, as is discussed in the next section.

\section{Ontology of Customary Property Rights}

Property rights are rights of ownership one has over material and immaterial things, grounded either in statutory or customary laws (Eggertsson, 1990) and are generally classified into customary, private and public. Customary and private lands are owned by various parties other than government and are subject to expropriation, while public land is under government or various communities as communal land or open access resources (Malawi Government, 2016). For the purposes of this analysis, only customary and private property rights are discussed in the following sections as they are expropriatable and compensable.

\subsection{Customary Property Rights}

Customary property rights are fashioned and guaranteed by customary norms and generally held as individual, communal or common/open access and are rarely registered (Chipeta, 1971). Allodial interest is the highest proprietary bundle under customary tenure (Malawi Government, 2002, Abdulai \& Ndekugri, 2008) normally entrusted with the community or chiefs (AduGyamfi, 2012). Individuals are mostly believed to have user rights, while 
permanent alienation rights remain with the chiefs (Cotula, 2007). According to Cotula and Vermeulen (2011), various governments consider most customary properties as public property.

Customary land is broadly acquired through traditional allocation by clan or family heads, inheritance (Tschirhart et al., 2016), and outright exchanges (Takane, 2008a, Haruna et al., 2013). Inheritance follows traditional (matrilineal, patrilineal, and mixed) practices while allocation to outsiders requires community consent. As Walker (2008) and Small and Sheehan (2008) contend, various emotional dynamics inform people's relationships to land and place, ascribed by their experiences and contexts, public discourse, social location and time. Consequently, some communities, like the Yoruba in Nigeria, consider land as the basis of creation, stories, religion, spirituality, art, and culture. Land is also considered to relate to living people, dead and future generations (Aluko et al., 2008), with various metaphysical values like inheritance and ritual sites, among others. Abstractly, customary properties characterise a complex social fabric that protects people through cultural membership (Xanthaki, 2003).

Generally, customary tenure prevails in most African countries as land is central to social, political and economic life, with a strong person-property attachment (Toulmin, 2009). However, customary property systems are modernising with increasing direct pecuniary exchanges (Cotula, 2004, Haruna et al., 2013) attributed to increasing land scarcity, among other factors (Takane, 2008a). Despite that, some of these direct purchases are authenticated through written agreements, but broadly customary property transactions are rarely registered. Consequently, information relating to the nature of properties, ownership and other transactions is seldom recorded, rarely available, and thus unsupportive of competitive property markets dependent on transactional evidence (Mooya, 2009a). Toulmin (2009) emphasises this by stating that most land in Sub-Saharan Africa and other parts of the world has no formal documentation of who owns it, or has rights to use it, owned collectively and inalienable. Prior to Toulmin (2009), De Soto (2000) contended that inadequate documentation of property rights means that such properties are technically known within their own settings and invisible to larger markets. De Soto adds that property documentation fixes the economic aspects of assets used to secure commercial and financial transactions. Yet most customary property systems lack this aspect, and thus cannot enjoy these benefits. Nor can the value basis that private and registered properties use be appropriately applied to these properties to quantify and attach a representative value to them.

\subsection{Private Property Rights}

Private ownership guarantees a known bundle of property rights with individual property title, certified and protected by government (Alston et al., 1999). Freehold is the highest bundle under private ownership from which other lesser interests, such as leasehold, are created (Mooya, 2009b). Unlike customary properties, Besley and Ghatak (2009) contend that individual title supports exchanging and mortgaging for financial facilities and assures property's optimal value. Accordingly, De Soto (2000) argues that this is because private (formal) property systems work like networks as all property 
records are continually tracked and protected as they are transacted, unlike customary properties. Because of these aspects private property systems catalyse competitive property markets that provide information on ownership, land details, prices, rentals, and other transactions that support valuation for different aims (Mooya, 2009a). Market data availability in private property settings thus supports objective market dealings (Furubotn \& Richter, 1998), expropriation and compensation assessment (Baum et al., 2008), among other benefits. However, this is not the case when dealing with customary properties. As such, the following section examines how the above compensation theories relate to customary property rights.

\section{Compensation Theories and Customary Property Rights}

This section analyses the application of current compensation aims, assessment basis and methodologies, and the challenges encountered when applied to customary properties.

\subsection{Compensation Aims and Customary Property Rights}

As discussed earlier, the aims of compensation is meant to protect property, deter arbitrary takings and restore expropriates. This section discusses these aims to see if the intended purposes are achieved when addressing customary property losses during expropriation.

\section{a) Safeguard Customary Property}

The presence of statutory title for private property ownership, with explicitly outlined rights and documented in land registries, strengthens its protection and compensation rights (Alston et al., 1999). Contrastingly, title to customary properties is only known to subject communities and enforced using customary norms and is normally undocumented in any government registry (Chipeta, 1971, Malawi Government, 2002). Further, constituent property rights for customary holdings are always complex as some extend beyond the physical assets one holds as discussed under ontology of customary property rights. Non-registration of these properties presumably leads to less statutory recognition, thereby weakening ownership and compensation rights. To confuse the situation further, many African governments controversially consider land under customary tenure as public property, and local users as squatters (Malawi Government, 2002, Cotula et al., 2009, Toulmin, 2009). Further, less tangible attributes of customary properties are barely appreciated by outsiders, including valuers and government officials (Anuar \& Daud, 2012). Such attributes include authority for decision-making on use of land one has for owning land under customary norms (Witter \& Satterfield, 2014). Further, Kombe (2010) and Witter and Satterfield (2014) contend that these aspects are normally uncompensated during expropriation, thus contributing to weaker protection for customary properties.

Practically, because constituent values of customary property rights are not well known, resulting compensations are rarely appropriate (Sheehan, 2000). Additionally, usurpation of ownership rights over customary land by various governments weakens its protection and compensation rights fundamentally, while actual expropriation and non-compensation catalyses insecurity and 
destruction of established livelihoods of affected people as observed in Africa (Cotula et al., 2009, Toulmin, 2009), Malaysia (Anuar \& Daud, 2012), Latin America and the Caribbean (Borras et al., 2012) as well as other parts of the world (Schmidt-Soltau, 2003, Asian Development Bank, 2007, Cernea, 2008). Furthermore, despite constitutional demands for appropriate compensation for expropriating customary land, various empirical works in Africa including Ambaye (2013) in Egypt, Chinsinga and Wren-Lewis (2013) in Malawi, Chachage (2010) in Tanzania, Famoriyo (1978) in Nigeria, Hall (2011) in Southern African countries, and Cotula and colleagues (2009) in several African countries, indicate endemic land takings without compensation. Where compensation is paid it is either inadequate, delayed, paid for improvements only and sometimes in instalments (Alemu, 2013). Generally, these tendencies make compensation an inefficient tool in protecting customary properties.

\section{b) Deter Arbitrary Acquisitions}

Presumably, in functional property markets, government competes, like other market participants, for resources. In expropriation government is the only buyer and competes with itself, and usually imposes unjustifiable prices for expropriated properties, which are often inadequate to counter losses suffered by expropriatees (Walker, 2008). This has been observed in several African countries including Ghana (Larbi et al., 2004), Mozambique (Witter \& Satterfield, 2014), Nigeria (Akujuru \& Ruddock, 2014), Tanzania (Kombe, 2010), and many others (Cotula \& Vermeulen, 2011). For example, in Malawi, biological asset prices gazetted in 2010 (Malawi Government, 2010), are still in use in 2018 without any provision for appreciation. This challenge is common in several African countries as established by Ambaye (2013), Kakulu (2008) and Msangi (2011). Furthermore, government assesses compensation for its own takings using those outdated rates and information and attain inappropriate values for compensation, which fail to thwart unjustifiable takings (Kasanga \& Kotey, 2001, Alemu, 2013). As Sulle \& Nelson (2009) and Cotula and Vermeulen (2011), among others, argue compensation procedures for customary properties are almost non-existent in many developing countries, and ambiguous where available. This contributes to wrong computations, lower compensation, and even no compensation at all, and encourages government to arbitrarily take more customary land than required. A case in point is a secondary school project in Accra, Ghana, that needed only 20 ha of land but acquired 167 ha without any justifiable reasons (Larbi et al., 2004).

Practically, there are times that customary land holders are ambushed by developers as government takes the land and allocates it without appropriately informing the owners. In a case in Ghana, Kasanga and Kotey (2001) established that affected landholders just saw newcomers working on their land without their permission or knowledge and when they went to complain to the Land Commission the land had already been subdivided and sold to the developers, by the very same Land Commission. These takings are arbitrary in nature and they have also been noted in Egypt (Alemu, 2013), Nigeria (Nuhu, 2008) and Tanzania (Kusiluka et al., 2011), among other counties. In many cases, expropriation lacks any strategic development programme, financial standpoints, and proper criteria (Larbi et al., 2004). These aspects expound the fear that some takings of customary land result 
from idiosyncratic decisions and actions of government (Nosal, 2001), thus contributing to arbitrary takings and impoverishment of expropriatees (Cernea, 2008).

\section{c) Restore Customary Property Expropriatees}

The need to restore expropriatees of customary land to their previous positions requires that constituent values of their property bundles, and hence consequential losses, be explicitly established, quantified, monetised (Sheehan, 2000), and appropriately compensated. For customary properties this is challenging since, apart from the material component, they are also characterised by an immaterial component, and are not defined by lines as private rights are (Simons et al., 2008). As discussed elsewhere, these immaterial aspects are not known by market value, and their losses mostly go uncompensated, at the detriment of the expropriatees. As Simons and Pai (2008) contend, some tribes are deeply attached with their lands spiritually and the right to land is vital for their survival and identities. Any attempt to place a pecuniary value on such lands has failed in many parts of the world as assessing such properties based on market value treats them as private lands, disregarding their various metaphysical aspects (Small \& Sheehan, 2008). Hence, it is hard to establish a definite bundle of rights for customary land and fully indemnify its expropriatory losses (Pachai, 1978) and rejuvenate expropriatees appropriately. Empirically, Witter and Satterfield (2014) in Mozambique, Kusiluka and others (2011) in Tanzania, Kakulu (2008) in Nigeria, Ambaye (2013) in Egypt, Anuar and Daud (2012) in Malaysia, Mitchell and colleagues (2015) in Australia, and other parts of the world (Simons \& Pai, 2008), established that such aspects as social and cultural linkages to gravesites, social networks, and hierarchies in a particular community, among others, are never compensated and hence permanently lost.

People in customary land settings also enjoy access to communal natural resources such as forests and their products, low-lying marshy areas for winter gardening and grazing animals, firewood picked from forests, medicines, various foods - honey, mushrooms, fruits, and bush meat, and many other benefits which are rarely compensated (Schmidt-Soltau, 2003, Sifuna, 2006, Witter \& Satterfield, 2014). As these lands are commonly considered public property, governments also take them idiosyncratically and without any compensation, against their own Constitutions and laws. This land grabbing phenomena has been established in various African countries (Kasanga \& Kotey, 2001, Cotula et al., 2009, Ambaye, 2013, Chinsinga \& Wren-Lewis, 2013), in Asia, Latin America and the Caribbean (Borras et al., 2012, Fairhead et al., 2012). Arbitrary acquisition or land grabbing and omission of some important losses in compensation defeats the primary goal of restoring affected people; preventing them from becoming poor and losing critical cultural and religious ties to the land they have resided upon since their births. Essentially, affected people have been emotionally harmed and impoverished in the long term as they never re-establish fully, if at all (Cernea, 1998, Xanthaki, 2003, Kaufman, 2010, Kusiluka et al., 2011).

From the preceding discussions, it seems that the theoretical goals of compensation of safeguarding property, deterring arbitrary expropriations, and restoring expropriated property owners may be applicable to customary 
properties. This is achievable if governments could respect the rule of law and adhere to stipulated procedures and standards that ensure that affected people are treated fairly with required compensation, where they are available. Additionally, compensation must consider the metaphysical values attached to customary properties if affected people are to be justly restored. However, various methodological challenges related to compensation assessment constrain these aspirations for customary properties as discussed in the following sections.

\subsection{Assessing Compensation for Customary Properties}

This section discusses market value as a basis for assessing customary properties for compensation purposes, and then covers the methods employed to compute market values, and the challenges encountered.

\section{a) Assessment Basis - Market Value}

As Mooya (2009a) expounds, market value is supposed to be an autonomous amount realised from objective valuations using quality market evidence obtained in a perfectly competitive market. However, Evans (2004) argues that essential conditions for a competitive market, such as many buyers and sellers, full information about the market and comparable properties in markets, among others, are rarely realised. Mooya (2009a) exemplifies this with a building valuation situation in the central business district of Windhoek, Namibia, where comparable market data to support that valuation was unavailable. Yet, through expertise, experience, and skill, the valuer created a figure that was readily accepted by the client for their purposes, even though it lacked external validation (Mooya, 2009a). Technically, an objective market value is seldom realised due to scarcity and high transaction costs for obtaining needed market data, even in well-established private property markets (Evans, 2004). As an example, Ghyoot (2008) highlights that accurate records of land ownership are available in various South African deeds offices, but their accessibility is hampered by high costs.

Practically, market evidence is even harder to get in customary property settings as documentation of rights and transactions is very minimal (De Soto, 2000), if any. De Soto contends that property systems with inadequate documentation of ownership, and their consequential transactions, generally suppress property markets, as observed in Egypt (Ambaye, 2013), Nigeria (Haruna et al., 2013), Malawi (Takane, 2008a), Tanzania (Msangi, 2011), and many other countries where customary tenure prevails. Obtainable market evidence relates to private property exchanges and is generally unsuitable for customary property valuation as the two property types are ontologically different with different value schema (Small \& Sheehan, 2008, Kabanga \& Mooya, 2017). Small and Sheehan further explicate that private property owes its value to its optimal material utility, while for customary tenure there is something more valuable to the holders, beyond occupational use rights that is metaphysical and non-commercial. For that reason market value fails as a fair basis and measure for compensation for customary properties as it cannot be autonomously validated because market evidence is lacking, and omission of some losses attached to customary properties that are invaluable to the affected people (Kaufman, 2010, Akujuru \& Ruddock, 2014). Where property markets are under-developed, dominated by customary land tenure, 
markets are no longer neutral gauges of property values as they do not meet required conditions. Fundamentally, market value cannot represent a fair price for the property and efficiently enable expropriatees to replace lost properties with their compensation. Essentially, resulting compensation sums fail to safeguard customary property, ensure non-arbitrary expropriations, and prevent expropriatees from becoming poor.

Technically, omission of non-market values is unsurprising because of the origins of market value: the Western world, where formal values are normally based on highest and best material utility and expressed in monetary terms (Small \& Sheehan, 2008). Furthermore, valuers are not trained to predict prices of metaphysical values and losses in the market (Kakulu, 2008, Mitchell et al., 2015), and thus ignore them. This deprives expropriatees of fair compensation. Principally, and similar to private properties, market value does not equal owner's loss for customary properties, and is hence, less ideal unless it accounts for the less tangible aspects, and a market with the required conditions exists to provide quality market data.

Theoretically, market value considers buyers and sellers as willing when exchanging properties. For expropriation, the parties are unwilling since transactions originate from the existence of public purposes. The buyer (government) is legally mandated to acquire any property for relevant public purposes, while owners may not have had any plans to alienate the properties at that particular juncture. This is vindicated by the need to warn property owners through notices of the intention to acquire property contained in various national laws. In Malawi, subsection 44(3) of the 1994 Constitution demands that property owners be adequately notified about impending expropriations (Malawi Government, 1994). Hence, statutes compel property owners to relinquish their properties unwillingly, and in some cases at gunpoint, as in South Africa during apartheid (Walker, 2008). Thus, both transacting parties are statutorily forced to exchange and so settings for the willing seller principle and expected market value of acquired properties are seldom obtained. For customary properties, the situation is even more difficult as it is not generally a commodified asset, with more sentimental and non-market values, and ownership that is intergenerational (Kasanga \& Kotey, 2001, Hall et al., 2015). These intrinsic values are mostly ignored in compensation procedures, and hence the final compensation itself (Small \& Sheehan, 2008).

For compensation quantum, market value of expropriated property is the key item. However, most customary land is either entirely omitted from compensation packages, or partially considered. According to Benson (2008), customary land was not compensated in former British colonies because it was abundant and easily replaceable. This is unfeasible nowadays as land is scarce and valuable. In Malawi, the growing scarcity of customary land is emphasised in the 2002 national land policy (Malawi Government, 2002). Other challenges for customary land compensation, as Anuar and Daud (2012), Kakulu (2008) and Walker (2008), among others contend, is to identify the real claimants and the extent of their shares in the property, and how to assess those shares justly for compensation purposes. 
For partial takings in which remaining land depreciates in value due to proposed uses of acquired land or actual project works, and such loss is compensable, reconciliation of land taken and remaining with owner for compensation aims is difficult as customary property rights are inexplicitly bound. This challenges computation of severance of land and consequential losses. For common resources where each community member benefits, how are these benefits assessed and compensated? Furthermore, how is loss of immaterial benefits handled using market value, which is indifferent to these immaterial benefits? These issues challenge assessment of compensation appropriate for customary properties and defy market-reliant methodologies.

For disturbance compensation, most aspects are financially computed and present no real challenge. For example, legal fees in cases of litigation can be obtained from legal practitioners while valuation fees can be obtained from valuers and government. Solatium is elusive where land is not compensable, since it is a proportion of total compensation. Sometimes special value compensation is required where special assets, like graves, are concerned. Akujuru and Ruddock (2014) highlight that affected rural people in Nigeria consider compensation adequate when their social and cultural values attached to the property are indemnified. This is also applicable in other parts of the developing world (Keon-Cohen, 2002, Keogh, 2003, Anuar \& Daud, 2012). However, estimation of compensation for such aspects is challenged by scarcity of market data, nature of benefits and losses under consideration, and nature of the basis and assessment methods. These drawbacks contribute to compensation that is inappropriate to restore affected people.

\section{b) Assessment Methods}

As discussed under compensation assessment basis and methods, comparison, income, and cost methods are commonly used in assessing market values for compensation purposes. Yet, in practice, market evidence for customary properties, or where property markets are under-developed, is scarce (Kakulu, 2008, Larbi, 2008, Msangi, 2011, Alemu, 2013), and valuation using comparative methods is difficult. Exchanges of customary properties are done under traditional practices (Takane, 2008a, Msangi, 2011, Ambaye, 2013, Haruna et al., 2013), and transactional data is scarce and costly to get, where available. For income capitalisation approaches, their application to customary properties is challenged by rarity of necessary data like rental income and discount rates as most customary properties are under own use, and rarely generate any income.

For cost methods, comparable land values and cost estimates for buildings is almost unavailable. Most customary properties are constructed from rudimentary materials that lack known costs, professional fees and labour charges. Depreciation data for such building materials as grass, trees and bamboo, among others, is non-existent. Such data gaps complicate use of cost approaches in valuing customary properties, obtaining compensation amounts without reasonable representation of actual properties or losses. Empirically, Kakulu (2008) established that using cost approaches to value mostly elementary properties for compensation purposes in rural areas in the Niger Delta in Nigeria realised lower values and contributed to inadequate compensation that frustrated affected people. Kakulu's research also highlights the dilemma faced in computing depreciation for highly 
rudimentary and non-exchangeable properties. These deficiencies have also been observed in Tanzania (Sulle \& Nelson, 2009) and Malaysia (Anuar \& Daud, 2012), among others. Such methodological deficiencies epitomise why market-dependent compensation assessments are largely inappropriate for highly non-market properties, and compensation that is mostly unacceptable to the expropriatees.

Broadly, where market data is inaccessible, comparison, income, and cost methods of assessing compensation are handicapped and bear values that do not adequately satisfy expropriatory losses suffered by customary property holders.

\subsection{Summary of Key Issues}

\section{a) Compensation Theories and Customary Property Rights}

As Kaufman (2010) explains, compensation is principally meant to prevent impoverishment of any person who losses his or her property for a public benefit. Thus, compensation is expected to equal actual expropriatory losses suffered, and not more or less. Theoretically, this core requirement of compensation is generally applicable to all expropriatable properties, including customary properties. By using market value as the basis for compensation for the various theories the presumption is that it will achieve this goal satisfactorily as expropriatees will be able to replace lost properties from the market and be appropriately re-established.

\section{b) Ontology of Customary Property Rights}

These properties generally have amorphous boundaries and are characteristically defined by both physical and non-physical aspects such as intergenerational ownership (ancestors, the living, dead and unborn (Abdulai \& Ndekugri, 2008)). The non-physical aspects challenge valuers in ably understanding, quantifying, monetising, and calculating representative figures as they do not exchange hands in commercial terms as private properties do. Hence such aspects are disregarded during compensation assessment and bear lower compensation that is unacceptable to the expropriatees. For compensation to reflect the true and actual losses suffered then customary properties must be treated in their entirety, together with their intangibles, and not like private properties during compensation assessment, or public properties during expropriation.

\section{c) Dominance of Customary Property Rights}

Dominance of customary property rights in Africa and other developing countries means that their transactions, as the subject property themselves, are seldom recorded in any register. Where some records exist, available data lacks in many aspects such as use of property and nature of transactions. Consequently, comparable market evidence to support objective valuation based on market value and market-reliant methods is scarce. This is more challenging when considering the immaterial aspects of the properties, which are rarely documented, quantified, and monetised. In such settings valuers need to use locally sourced data on how exchanges are conducted based on local transactions, as long as it is acceptable to the concerned parties and serves the purposes at hand, without necessarily sticking to market value 
dictates, and importing unfitting data from elsewhere, as argued by Mooya (2009a).

\section{d) Use of Market Value as a Compensation Basis}

Market value is generally applied as a basis for assessing compensation during expropriation with the belief that it will enable expropriatees to replace lost properties from the market. In the absence of functional property markets in customary property dominated environments in Africa and elsewhere, it is difficult to attain reasonable amounts to represent expropriatory losses and appropriately restore affected people. Market value basis and its techniques are thus a challenge for customary properties. The situation worsens as no alternative valuation bases and methods are provided for by relevant laws in these countries. The failure of market value to fulfil intended purposes of compensation for customary properties thus calls for alternative valuation bases and methods.

\section{e) Use of Market Value as a Compensation Basis}

As Denyer-Green (2014) contends, assessing market values for compensation aims is presumably done by ably trained and professional valuers in countries with well-established property markets and dominated by private property rights, like the United Kingdom. However, in most developing countries where customary property rights excel, including Egypt (Ambaye, 2013), Malaysia (Anuar \& Daud, 2012), Nigeria (Kakulu, 2008), Tanzania (Sulle \& Nelson, 2009), Papua New Guinea (Bannerman \& Ogisi, 1994), among others, property assessments for compensation are done by mostly inexperienced people. For example, in Egypt, assessments are normally done by valuation committees, comprising local community leaders, engineering professionals and others without any valuation knowledge and skills (Ambaye, 2013). In Nigeria, some assessments in rural areas are done by claim agents, apart from trained valuers (Kakulu, 2008). Broadly, some of these assessors are academically qualified (Kakulu, 2008) but lack relevant knowledge, skill, and experience for dealing with customary properties. Among other factors, this challenge is blamed on the type of training that valuers get as it is mostly based on Western curricula that rarely cover customary or native rights (Kakulu, 2008, Mitchell et al., 2015). Thus, such valuers wrongly treat customary property rights as private and transactable during compensation assessment. Similarly, use of inexperienced and nontrained assessors is blamed on scarcity of trained valuers (Ambaye, 2013), and mistrust towards government valuers by expropriatees, as in Nigeria (Kakulu, 2008). All these capacity deficiencies undermine use of market value as a reliable compensation basis.

Broadly, the above issues contribute to amounts that are purported to be market values, yet they are created subjectively based on data that does not meet market value requirements, and by less qualified and less experienced people. Additionally, some values are created by valuers using their expertise and experience where data is unavailable (Mooya, 2009a). At best, these figures are market values without a market (Evans, 2004, Mooya, 2009a, Kaufman, 2010, Ambaye, 2013) that do not offer adequate restoration of expropriatees. 


\section{Conclusions and Recommendations}

Fundamentally, the analysis shows that current compensation theories are applicable to customary properties as they mainly aim at protecting property and preventing expropriatees from becoming poor. Whilst this compensation goal is fairly achievable for private property owing to realisation of fair market values where market evidence is accessible, there are various ontological and methodological challenges when it comes to customary properties. Market value is principally challenged by the nature of customary properties, which are conceptually non-exchangeable; scarcity of comparable market evidence to support objective valuations and realise reasonable market values; and use of improperly trained agents and people as compensation assessors. Market value is hence not an ideal basis for assessing compensation for customary property as, in addition to being inadequately compensated, expropriatees may become destitute.

Furthermore, this theoretical analysis shows that the nature of customary property rights leads to difficulties in establishing the actual property rights bundle to assess during expropriation, quantifying, and monetising material and intangible losses. Principally, customary property rights are often misinterpreted and undervalued as they do not conform to common standards of market value, the very basis used to monetise them through market-reliant methods. These deficiencies are common where property markets are underdeveloped, and where customary properties dominate or are virtually nonexistent. As market value basis and market-reliant assessment methods are unsuitable in these settings, it is recommended that further research be conducted to find alternative bases and methods of assessing compensation that recognise customary property rights in their entirety and not treat them as private ones. Further, such bases and methods should be able to use available data in particular settings, and not only data that meets market value criteria for assessing compensation for customary properties. It is argued that this is required to address current shortfalls.

The study further recommends that curricula regarding land administration and property valuation be improved to include customary property rights as part of their syllabi, and not only promulgate statutes that favour privatisation of customary properties. As such, research on the current content of various curricula in areas related to land, expropriation and compensation in Africa, and valuation theory and customary property rights, is necessary to feed into the development of the new or improved curricula, market bases and methods, and policy.

\section{References}

Abdulai, R.T. \& Ndekugri, I.E. (2008). Indigenous Landholding Institutions as an Impediment to Economic Use of Land: Case Studies of Tamale and Bolgatanga in Ghana. In Simons, R.A., Malmgren, R. \& Small, G. (eds.) Indigenous Peoples and Real Estate Valuation. New York : Springer. 
Adu-Gyamfi, A. (2012). An Overview of Compulsory Land Acquisition in Ghana: Examining Its Applicability and Effects. Environmental Management and Sustainable Development, 1(2), pp.187-203.

Akujuru, V.A. \& Ruddock, L. (2014). The Determination of Compensation Payable in the Niger Delta for Compulsory Acquisition and the Need for a Sustainable Practice. Journal of Sustainable Development in Africa, 16(2), pp.102-114.

Alemu, B.Y. (2013). Expropriation, Valuation and Compensation in Ethiopia. PhD, Royal Institute of Technology (KTH), Stockholm, Sweden.

Alias, A. \& Daud, M.N. (2012). Compensation for Orang Asli native land in Malaysia: The perceptions and challenges in its quantification. Journal of Design and Built Environment, 4(1), pp.63-84.

Alias, A., Yanning, P. \& Hanif, N.R. (2006). Land Acquisition Problems in China - Adopting Land Acquisition Act. Journal of Design and Built Environment, 8(1), pp.1-22.

Alston, L.J., Libecap, G.D. \& Mueller, B. (1999). Titles, conflict and land use: the development of property rights and land reform on the Brazilian Amazon frontier, University of Michigan Press, Michigan, USA.

Aluko, B.T., Omisore, E.O. \& Amidu, A.-R. (2008). Valuation of Yoruba Sacred Shrines, Monuments, and Groves for Compensation. In: Simons, R.A., Malmgren, R. \& Small, G. (eds.) Indigenous Peoples and Real Estate Valuation. New York: Springer.

Ambaye, D.W. (2013). Land Rights and Expropriation in Ethiopia. PhD, Royal Institute of Technology (KTH), Stockholm, Sweden.

Asian Development Bank (2007). Compensation and Valuation in Resettlement: Cambodia, People's Republic of China, and India, Asian Development Bank, Manila, Philippines.

Bannerman, S. \& Ogisi, F. (1994). Valuation of customary land in Papua New Guinea-principles versus local realities. FIG-International Federation of Surveyors XX Congress, 1994. International Federation of Surveyors, Melbourne, Australia, pp.1-12.

Barnes, M. (2014). The Law of Compulsory Purchase and Compensation, Hart Publishing Ltd, Oxford, UK.

Baum, A., Sams, G., Ellis, J., Hampson, C. \& Stevens, D. 2008. Statutory valuations, Taylor \& Francis, Reading, UK.

Benson, B.L. (2008). The evolution of eminent domain: a remedy for market failure or an effort to limit government power and government failure? The independent review, 12(3), pp.423-432.

Besley, T.J. \& Ghatak, M. (2009). Property rights and economic development. In Rodrik, D. \& Rosenzweig, M. (eds.) Handbook of Development Economics. London: Economic Organisation and Public Policy Programme.

Blackledge, M. (2009). Introducing Property Valuation. London: Routledge.

Blackstone, W. (1872). Commentaries on the laws of England: In four books. London: Callaghan.

Borras, S.M., Franco, J.C., Gómez, S., Kay, C. \& Spoor, M. (2012). Land grabbing in Latin America and the Caribbean. The Journal of Peasant Studies, 39(3-4), pp.845-872.

Cernea, M. (1998). Impoverishtnent or social justice? A model for planning resettlement, Oxford University Press, Oxford, New Delhi. 
Cernea, M. (2008). Compensation and benefit sharing: Why resettlement policies and practices must be reformed. Water Science and Engineering, 1(1), pp.89-120.

Chachage, C. (2010). Land Acquisition and Accumulation in Tanzania: The Case of Morogoro, Iringa and Pwani. Dar es Salaam, Tanzania.

Chinsinga, B. \& Wren-Lewis, L. (2014). Grabbing land in Malawi. In Soreide, T. \& Williams, A. (eds.) Corruption, Grabbing and Development: Real World Challenges. Cheltenham, UK: Edward Elgar Publishing Limited.

Chipeta, W. (1971). Land tenure and problems in Malawi. The Society of Malawi Journal, 24(1), pp.25-34.

Cotula, L. (2004). Securing the commons in an era of privatisation: Policy and legislative challenges. In Quan, J., Tan, S.F. \& Toulmin, C., (eds.) Land in Africa: Market asset or secure livelihood? Proceedings and summary of conclusions from the Land in Africa Conference held in London, 8-9 November 2004, London: Russell Press.

Cotula, L. (ed.) (2007). Changes in customary land tenure systems in Africa: London: Russell Press.

Cotula, L. \& Vermeulen, S. (2011). Contexts and Procedures for Farmland Acquisitions in Africa: What outcomes for local people \& quest. Development, 54(1), pp.40-48.

Cotula, L., Vermeulen, S., Leonard, R. \& Keeley, J. (2009). Land grab or development opportunity?: agricultural investment and international land deals in Africa. London: IIED.

De Soto, H. (2000). The mystery of capital: Why capitalism triumphs in the West and fails everywhere else. Bantam Press.

Deininger, K.W. (2003). Land policies for growth and poverty reduction: A World Bank policy research report, World Bank Publications and Oxford University Press, Washington DC, USA.

Denyer-Green, B. (2014). Compulsory Purchase and Compensation. London and New York: Routledge.

Du Plessis, E.W.J. (2009). Compensation for Expropriation under the Constitution. $\mathrm{PhD}$, Stellenbosch University, South Africa.

Eggertsson, T. (1990). The role of transaction costs and property rights in economic analysis. European Economic Review, 34(2-3), pp.450-457.

Evans, A.W. (2004). Economics, real estate and the supply of land. Oxford: Blackwell Publishing.

Fairhead, J., Leach, M. \& Scoones, I. (2012). Green Grabbing: a new appropriation of nature? Journal of Peasant Studies, 39(2), pp.237261.

Famoriyo, S. (1978). Land tenure, land use and land acquisition in Nigeria, Publisher not identified.

Famuyiwa, F. (2011). Infrastructure Provision and Private Lands Acquisition Grievances: Social Benefits and Private Costs. Journal of Sustainable Development, 4(6), pp.169-180.

Food and Agricultural Organisation (2012). Voluntary Guidelines on the Responsible Governance of Tenure of Land, Fsheries and Forests in the Context of National Food Security, FAO, Rome, Italy.

Fortes, R. (2005). Compensation models for native title. Eleventh annual conference of the Pacific Rim Real Estate Society, Melbourne, Australia. pp.23-27. 
Furubotn, E.G. \& Richter, R. (1998). Institutions and economic theory: the contribution of the new institutional economics, The University of Michigan Press, USA.

Ghyoot, V. (2008). Land Restitution and Restitution Valuation in South Africa. In: Simons, R.A., Malmgren, R. \& Small, G. (eds.) Indigenous Peoples and Real Estate Valuation. New York: Springer.

Hall, R. (2011). Land grabbing in Southern Africa: the many faces of the investor rush. Review of African Political Economy, 38(128), pp.193214.

Hall, R., Edelman, M., Borras, S.M., Scoones, I., White, B. \& Wolford, W. (2015). Resistance, acquiescence or incorporation? An introduction to land grabbing and political reactions 'from below'. The Journal of Peasant Studies, 42(3-4), pp.467-488.

Haruna, A., Ilesanmi, F.A. \& Yerima, B.D. (2013). Problems of Formal Land Acquisition Policies in Nigeria: The Case of Jimeta-Yola, Adamawa State, Nigeria. Journal of Environment and Earth Science, 3(11), pp.1-10.

International Valuation Standards Council (2017). International Valuation Standards, International Valuation Standards Council, London, UK.

Kabanga, L. \& Mooya, M.M. (2017). Assessing compensation for customary property rights in Malawi: the case of Mombera university project. African Journal of Rural Development, 2(4), pp.483-496.

Kakulu, I.I. (2008). An Ananlysis of Processes and Methods in Compulsory Land Acquisition and Compensation in Nigeria. PhD, Reading, United Kingdom.

Kasanga, K. \& Kotey, N.A. (2001). Land Management in Ghana: Building on Tradition and Modernity, International Institute for Environment and Development, London, UK.

Kaufman, W. (2010). How fair is market value? An appraiser's report of the temptations, deficiencies, and distortions in the condemnation process. In: Benson, B.L. (eds.) Property rights: eminent domain and regulatory takings re-examined. New York: Palgrave Macmillan.

Kelly, D.B. (2006). The "Public Use" Requirement in Eminent Domain Law: A Rationale Based on Secret Purchases and Private Influence. Cornell Law Review, 92(1), pp.1-66.

Keogh, J. (2003). The "Special Value" of Land in Compulsoru Acquisition Cases. A summary of the legal approaches to a contentious issue in valuation practice. Pacific Rim Real Estate Society Ninth Annual Conference 19-22nd January 2003. Brisbane, Australia.

Keon-Cohen, B. (2002). Compensation and Compulsory Aquisition Under the Native Title Act 1993. Monash University Law Review, 28(1), pp.17-58.

Kombe, W. (2010). Land acquisition for public use, emerging conflicts and their socio-political implications. International Journal of Urban Sustainable Development, 2(1-2), pp.45-63.

Kratovil, R. \& Harrison, F.J. (1954). Eminent Domain Policy and Concept. California Law Review, 42(4), pp.596-652.

Kusiluka, M.M., Kongela, S., Kusiluka, M.A., Karimuribo, E.D. \& Kusiluka, L.J.M. (2011). The negative impact of land acquisition on indigenous communities' livelihood and environment in Tanzania. Habitat International, 35(2011), pp.66-73. 
Larbi, W.O. (2008). Compulsory Land Acquisition and Compensation in Ghana: Searching for Alternative Policies and Strategies. FIG/FAO/CNG International Seminar on State and Public Sector Land Management Verona, Italy, .

Larbi, W.O., Antwi, A. \& Olomolaiye, P. (2004). Compulsory land acquisition in Ghana-policy and praxis. Land Use Policy, 21(2), p.115-127.

Malawi Government (1994). The Constitution of the Republic of Malawi. Lilongwe, Malawi.

Malawi Government (2002). Malawi National Land Policy. Lilongwe, Malawi.

Malawi Government (2010). Florestry Act, 2010. Lilongwe, Malawi.

Malawi Government (2016). Land Act, 2016. Lilongwe, Malawi.

Mitchell, D., Myers, M. \& Grant, D. (2015). Land valuation: a key tool for disaster risk management. Land Tenure Journal, 1(14), pp.35-69.

Mooya, M.M. (2009a). Market value without a market: Perspectives from transaction cost theory. Urban Studies, 46(3), pp.687-701.

Mooya, M.M. (2009b). Real estate markets and poverty alleviation in Namibia's urban informal settlements: an institutional approach. $\mathrm{PhD}$, University of Pretoria, Pretoria, South Africa.

Msangi, D.E. (2011). Land Acquisition for Urban Expansion: Process and Impacts on Livelihoods of Peri Urban Households, Dar es Salaam, Tanzania. Urban and Rural Development Department, Swedish University of Agricultural Sciences, Uppsala, Sweden.

Nosal, E. (2001). The taking of land: Market value compensation should be paid. Journal of Public Economics, 82(3), pp.431-443.

Nuhu, M.B. (2008). Compulsory Purchase and Payment of Compensation in Nigeria: A Case Study of Federal Capital Territory (FCT) Abuja. Nordic journal of surveying and real estate research, 3(2008), pp.102-126.

Pachai, B. (1978). Land and Politics in Malawi, 1875-1975. Kingston, Ontario: The Limestone Press.

Radin, M.J. (1982). Property and personhood. Stanford Law Review, 34(5), pp.957-1015.

Scarrett, D. (2008). Property valuation: The five methods. London and New York: Routledge.

Schmidt-Soltau, K. (2003). Conservation-related Resettlement in Central Africa: Environmental and Social Risks. Development and change, 34(3), pp.525-551.

Sheehan, J. (2000). Assessing Compensation for Native Title: A Valuation Perspective. Pacific Rim Property Research Journal, 6(1), pp.43-56.

Sifuna, N. (2006). Using Eminent Domain Powers to Acquire Private Lands for Protected Area Wildlife Conservation: A Survey under Kenyan Law',. Law, Environment and Development Journal, 2(1), pp.86-105.

Simons, R.A., Malmgren, R. \& Small, G. (2008). Introduction to the ARES Monograph on Indigenous Peoples and Real Estate Valuation. In: Simons, R.A., Malmgren, R. \& Small, G. (eds.) Indigenous Peoples and Real Estate Valuation. New York: Springer.

Simons, R.A. \& Pai, S.H. (2008). Indigenous Land Claims in Canada: a Retrospective Analysis. In: Simons, R.A., Malmgren, R. \& Small, G. (eds.) Indigenous Peoples and Real Estate Valuation. New York: Springer. 
Small, G. \& Sheehan, J. (2008). The metaphysics of Indigenous ownership: Why Indigenous ownership is incomparable to Western conceptions of property value. In: Simons, R.A., Malmgren, R. \& Small, G. (eds.) Indigenous Peoples and Real Estate Valuation. New York: Springer.

Sulle, E. \& Nelson, F. (2009). Biofuels, land access and rural livelihoods in Tanzania. London: IIED.

Takane, T. (2008). Customary Land Tenure, Inheritance Rules, and Smallholder Farmers in Malawi. Journal of Southern African Studies, 34(2), pp.269-291.

Toulmin, C. (2009). Securing land and property rights in sub-Saharan Africa: the role of local institutions. Land Use Policy, 26(1), pp.10-19.

Tschirhart, N., Kabanga, L. \& Nichols, S. (2016). The convergence of HIV/AIDS and customary tenure on women's access to land in rural Malawi. SAHARA-J: Journal of Social Aspects of HIV/AIDS, 12(1), pp.134-146.

Walker, C. (2008). Landmarked: land claims and land restitution in South Africa. Sunnyside, South Africa: Jacana Media.

Witter, R. \& Satterfield, T. (2014). Invisible losses and the logics of resettlement compensation. Conservation Biology, 28(5), pp.13941402.

Xanthaki, A. (2003). Land rights of indigenous peoples in South-East Asia. Melb. J. Int'l L., 4, pp.1-30.

Xanthaki, A. (2007). Indigenous rights and United Nations standards: selfdetermination, culture and land, Cambridge University Press. 